\title{
Stresszkezelés és kiégésmegelőzés hatékony módszereinek szakirodalmi áttekintése
}

\author{
Evidence-based interventions for stress management \\ and burnout prevention
}

Szerzők: $\quad$ Salavecz Gyöngyvéra,b $₫$, Pálinkás-Holovits Zsuzsannaa , Handa Orsolyaa , Vig Katalina, Rusznyák-Pethő Anikóa, Szabó Gabriella

a: Nemzeti Népegészségügyi Központ, Budapest, b: Semmelweis Egyetem, Magatartástudományi Intézet, Budapest

Beküldve: 2020. 04. 23.

doi: $\quad$ 10.24365/ef.v61i2.591

\begin{abstract}
Összefoglaló: A stresszkezelő módszerek alkalmazása egészséges munkavállalóknál csökkentheti a mentális és testi betegségek kialakulásának esélyét. Különösen magas stressznek kitett csoporthoz tartoznak az egészségügyben dolgozók és a pedagógusok. Vizsgálatunk célja, hogy metaanalízisek és szisztematikus szakirodalmi áttekintések összefoglalói alapján ezekben a célcsoportokban a stresszkezelő és kiégésmegelőző módszereknek a hatékonyságát tekintsük át, amelyek hazánkban hozzáférhetőek (mindfulness alapú beavatkozások, kognitív viselkedésterápiás és relaxációs módszerek). Mindhárom módszer különböző evidenciaszintek mellett, de hatékonynak bizonyult a stressz és a kiégés tüneteinek csökkentésében. Az egészségmegőrzés érdekében jelen összefoglaló alapján javasolt a vizsgált stresszkezelő módszerek alkalmazása egészséges munkavállalók körében.
\end{abstract}

Kulcsszavak: stressz; kiégés; stresszkezelés; mindfulness; relaxáció

Summary: Applying stress management techniques for healthy workers may reduce their chances of developing mental and physical illness. Healthcare professionals and teachers are particularly vulnerable of high stress. The aim of our study is to examine the effectiveness of stress management and burnout prevention methods that are available in Hungary (mindfulness-based methods, cognitive-behavioral therapy and relaxation methods) in these target groups in summaries of systematic reviews and meta-analyses. All three methods have been shown to be effective in reducing stress and burnout symptoms at different levels of evidence. For the sake of health preservation, it is recommended to use the stress management methods examined among healthy workers based on this summary.

Keywords: stress; burnout; stress management; mindfulness; relaxation

\section{BEVEZETÉS}

\section{Stressz és kiégés}

A stressz több pszichofiziológiai reakcióból álló összetett folyamat, amely az egyén különböző helyzetekhez való alkalmazkodását, a testi-lelki egyensúly helyreállítását segíti. ${ }^{1}$ A stressznek nem csak árnyoldala létezik, mivel biztosítja az élethez elengedhetetlen motivációt, mellyel a fejlődés szolgálatában áll. Hatása attól függ, hogy milyen mértékben veszi igénybe az alkalmazkodóképességet.

A stresszállapotra számos tünet jellemző, mint például a fokozott vegetatív múködés, magas vérnyomás, a vérzsírok és a vércukor szintjének növekedése, továbbá megváltozik a véreloszlás, 
a szív és a tüdő múködése fokozódik, a vese kiválasztó funkciója csökken, az izmok feszítettségi állapota nő, lassul az emésztés. ${ }^{2}$ A stresszválasz alul- vagy túlműködése jelentős számú betegség kialakulásának kockázatát növeli. ${ }^{3} \mathrm{~A}$ krónikus, hoszszú ideje fennálló stressznek pedig jelentős szerepe van számos megbetegedés kialakulásában. ${ }^{4}$ Legszorosabb kapcsolata a szív- és érrendszeri megbetegedésekkel és a korai halálozással van. ${ }^{5}$ A stressz a neuroendokrin rendszeren keresztül váltja ki hatását a szervezetben és készteti az egyént olyan viselkedésre, amely lehetővé teszi az alkalmazkodást. A stressz tehát kikerülhetetlen, az élet velejárója, fogantatásunktól kezdve életünk végéig elkísér, csak a mértéke és a tartóssága változó.

Fontos egy másik, szintén egyre gyakrabban előforduló jelenségről, a kiégésről is szólni. A kiégés tulajdonképpen a stresszfolyamat része, amely során az egyén fizikai, kognitív és érzelmi energiája jelentősen lecsökken. A kiégés a fizikai, érzelmi és mentális kimerültség állapota, amely a krónikus emocionális megterhelések, stresszhatások következtében alakul ki. Ezek legtöbbször a munkahelyi környezethez köthetők. Kiégés állapotában jellemző a kilátástalanság, reménytelenség, inkompetenciaérzés, valamint az egyén saját magára, a munkára és másokra vonatkozó negatív attitǔdje. ${ }^{6}$

A kiégés fogalma elsősorban munkahelyi kontextusban használatos, azonban felmerül a definíciója alapján is, hogy nemcsak munkahelyi, hanem az egyéni élet egyéb területén is megjelenő, azonos jelenség megnevezésére is alkalmas. ${ }^{7}$

A kiégést három dimenzióval jellemezhetjük: 1, egyéni aspektus során eluralkodik az érzelmi kimerültség, fő tünete az érzelmi és fizikai kimerülés, az empátiás kapacitás jelentősen csökken; 2 , interperszonális szint fő tünete a depreszonalizáció, a másoktól való elidegenedés, távolságtartás a társas kapcsolatokban; 3, csökken a kompetencia érzés és a produktivitás, az egyén úgy érzi, képtelen megfelelően teljesíteni. ${ }^{8}$

\section{Stresszkezelés módszerei}

Vizsgálatunk az alábbi stresszkezelő módszerekre fókuszál: mindfulness alapú beavatkozások, a kognitív-, viselkedésterápia és a relaxációs módszerek csoportja. A mindfulness módszer Magyarországon elérhető, azonban jelenleg csak korlátozottan hozzáférhető. Várakozásaink szerint ez az elkövetkező években pozitív változást fog mutatni, hiszen a módszer rendkívül népszerû a lakosság körében is, és a mindfulness tanári cím megszerzése egyéb (nem humán) diplomával is elsajátítható. A kognitív viselkedésterápiás módszer Magyarországon viszonylag széles körben elérhető, CBT (kognitív viselkedésterápiás) konzultáns képzés elvégzésével segítő szakmabeliek alkalmazhatják mentálisan egészségesek körében prevenciós célzattal. A relaxációs módszerek közül az autogén tréning Magyarországon szintén széles körben hozzáférhető, hiszen humán diplomával megszerezhető a relaxációs gyakorlatvezető végzettség és az ország több nagyvárosában (pl. Debrecen, Szeged, Sopron, Pécs stb.) is van erre lehetőség. Ezeknek a módszereknek az oktatási jogosultságai az éppen aktuálisan hatályban lévő rendeletek tükrében változhatnak. A következő részben röviden bemutatjuk ezeket a módszereket.

\section{Relaxációs módszerek: autogén tréning, progresszív relaxáció}

Az autogén tréning Heinrich Schultz nevéhez füződő relaxációs módszer, amelyet a hipnózisból fejlesztettek ki. Gyakorlása során kutatásokkal bizonyított kedvező fiziológiai folyamatok indulnak meg a szervezetben (pl. légzés, szívritmus rendeződése), melyek a test öngyógyító folyamataival függenek össze. Az autogén tréning gyakorlása során magunkra irányuló passzív figyelemmel képesek vagyunk létrehozni a testi-lelki ellazultságot, előidézve ezzel a paraszimpatikus vegetatív múködést. Ezáltal csökkenteni tudjuk a stressz ártalmas hatásait, a szorongást és növeljük a szervezet önszabályozó képességét. A módszer hatása a következő aspektusokban mutatkozik meg: a testi funkcióik normalizálása, pszichésen nyugodt állapot elérése, a koncentráció, a kreativitás és a problémamegoldás előmozdítása. ${ }^{7}$ Gyakorlottság birtokában testi és mentális múködésünket képesek vagyunk szabályozni aktuális szándékainknak, céljainknak megfelelően. ${ }^{8}$ A módszer elsajátításához kb. tizenkét hetes, napi gyakorlásra van szükség. A gyakorlatok hetente egymásra épülnek, elsajátítását követően bárhol, bármilyen testpozícióban végezhetők. Az alkalmak között célszerú írásban naplót vezetni az élményekről, amely segíti a folyamat elmélyítését és a tapasztalatok összegzését. 
A progresszív relaxáció az aktív (muszkuláris) relaxációhoz tartozik, melynek célja a testi állapot tudatosítása, a felesleges izomfeszülések kikapcsolása a rendszeres tónusszabályozás által. A módszer Edmund Jacobson nevéhez füződik és azon a tényen alapszik, hogy a test izmai szorongást, feszültséget kiváltó helyzetekben automatikusan megfeszülnek. ${ }^{8}$ Az izmok további feszítése azok elernyedéséhez fog vezetni, amely az ellazultság kellemes érzésével párosul. ${ }^{7}$ A relaxációs beavatkozások kifejezetten ajánlottak szorongásos zavarok, pszichoszomatikus és szomatikus betegségek, kimerültség, depresszió, stressz, alvászavarok, indulatkezelési problémák esetén. A módszer a Magyar Relaxáció és Szimbólumterápiás Egyesületnél sajátítható el. Jelenleg a képzés felsőfokú humán diplomával elvégezhető, azonban alkalmazhatósága csak azon kliensek körére terjed ki, akiket az adott szakembernek kompetenciája alapján joga van elvállalnia.

\section{Mindfulness, tudatos jelenlét alapú módszerek}

A mindfulness angol szót magyarra általában tudatos jelenlétként fordítjuk, eredetileg azonban mindössze annyit jelent: „tudatosság”, „figyelem”. Alapvetően arra a folyamatra utal, amikor figyelmünket szándékosan és ítélkezésmentesen a jelen pillanat tapasztalatai felé fordítjuk, és a pillanatnyilag észlelhető belső és külső tapasztalatokat tudatosítjuk.

A Mindfulness-Based Stress Reduction (MBSR) mindfulness alapú stresszcsökkentés tanfolyamának formátumát Jon Kabat-Zinn és munkatársai dolgozták ki a Massachusettsi Egyetemen 1979ben. Az MBSR főként buddhista meditációs módszerekre, illetve részben hatha jógára alapozott önsegítő program. Mióta a Massachusettsi Egyetem Stresszklinikáján kidolgozták, és 1979-ben alkalmazni kezdték ezt a programot, a mindfulness szinte világméretű mozgalommá vált, különösen az angolszász országokban terjedt el. Számos új, tudományosan is akkreditált módszer született azóta. Az alábbi főbb tanfolyamtípusokat különböztethetjük meg: 1, Mindfulness-Based Stress Reduction (MBSR) mindfulness alapú stresszcsökkentés; 2, Mindfulness-Based Cognitive Therapy (MBCT) mindfulness alapú kognitív terápia; 3, Breathworks (Mindfulness alapú betegségteher- és fájdalomcsökkentő program); 4, Mindfulness-Based Living Course (MBLC) mindfulness alapú életvitel; 5, Mindfulness-Based Childbirth and Parenting
(MBCP) Mindfulness-alapú szülés és gyereknevelés; 6, Mindfulness-Based Relapse Prevention for Addictive Behaviors (MBRP) Mindfulness alapú visszaesés-prevenció függők számára.

A tudatos jelenlét meditációinak hasznát jelentős mértékű tudományos kutatás támasztja alá. Azok az MBSR programok, amelyek meditációs komponenst is tartalmaznak, képesek a legerősebb hatást gyakorolni a pszichológiai jóllétre. ${ }^{9}$ Eberth és Sedlmeyer vizsgálatai szerint az MBSR bizonyítottan sokat segít a stressz, a szorongás, valamint a negatív érzelmek csökkentésében és a magasabb szintű jóllét kialakításában. Az MBSR különösen hatékony a stressz kezelésében. Fontos megemlíteni, hogy a prefrontális kéreg aktivitásának a növekedése MBSR során az agy újrahuzalozási tevékenységére utal, mely során a tudatos figyelem fenntartásával csökkenthető a túlzott érzelmi reakció és ezáltal egy sokkal kiegyensúlyozottabb testi és lelki állapot érhető el. ${ }^{10}$ A hétköznapi stressz csökkentésén túl számos mentális és testi probléma esetén is bizonyítottan hatékony módszer lehet (pl. fájdalomzavar és krónikus fájdalmak, alvászavar, a depresszióba való visszaesés megelőzése, evészavarok, függőségek, ADHD, pánikzavar esetén).

A mindfulness, tudatos jelenlét alapú programok általában nyolc hetesek. Ezeknek a programoknak az általános jellemzői: racionális alapokon nyugszanak, nem vallásos, szekularizált megközelítésűek; tanár vezeti őket; úgy kerültek kialakítására, hogy mérhetők legyenek; rögzített tanterven alapulnak, melyek minimum 8 foglalkozást tartalmaznak; legalább 30-45 perc otthoni gyakorlást feltételeznek; személyes fejlődésre és tapasztalati tanulásra építkeznek; nyíltan elköteleződnek a bizonyítékokkal alátámasztott megközelítés mellett. ${ }^{11,12}$

A mindfulness alapú megközelítésekkel dolgozó tanároknak el kell sajátítania a mindfulness alapú kurzusok megtanítandó tananyagát, különös tekintettel a tanfolyamok magját jelentő meditációs gyakorlatok személyes, elmélyült megtapasztalására. Ez a tanulás és tapasztalás egyéni vagy csoportos kurzuson való részvételt feltételez. A tanári képzések minimum 12 hónapos mindfulness alapú tanárképző programot tartalmaznak, és ezt követően szupervíziós folyamatban való részvételt írnak elő. Fontos az elkötelezettség a személyes mindfulness gyakorlás mellett, amely napi formális és informális gyakorlásban, illetve évente legalább egy, tanár által vezetett mindfulness meditációs elvonuláson való részvételben valósul meg. Emellett elvárt 
olyan pszichológiai, egészségügyi, oktatási vagy szociális téren megszerzett végzettség, illetve azzal ekvivalens élettapasztalat, mint amilyet a mindfulness tanítás szervezeti környezete megkövetel.

Magyarországon eddig két alkalommal MBCT tanárképzés valósult meg a Mindfulness Egyesület és az Oxford Mindfulness Center (OMC) szervezésében. A képzés tapasztalt, az OMC nemzetközileg elismert oktatói végezték. Az MBCT tanítása esetén szükséges a releváns, alapvető pszichológiai folyamatok, a kapcsolódó kutatások és a bizonyítékokkal alátámasztott gyakorlat ismerete és a megfelelő szakmai - célcsoporttól függően a klinikusi képzettség. ${ }^{11,12}$

\section{Kognitív viselkedésterápia (CBT)}

A kognitív viselkedésterápia alapelvét Aaron Beck dolgozta ki az 1960-as években. Alapfeltevése, hogy az emberek hiedelmei meghatározzák a világhoz való hozzáállásukat, viselkedésüket és érzelmi megnyilvánulásaikat. Ugyanarra a történésre másmás reakciót adhatnak, és az értelmezésüket befolyásolják a múlt történései is a korai gyerekkorban kialakult maladaptív sémákon keresztül. Egy adott helyzet félreértelmezése a kora gyerekkori maladaptív sémák aktivizálódásán keresztül vezet negatív automatikus gondolatokhoz, diszfunkcionális attitúdökhöz és kognitív torzításokhoz (pl. „Nekem semmi sem sikerül.”), végül pedig a zavar maladaptív viselkedés formájában nyilvánul meg (pl. problémák elkerülése anélkül, hogy megpróbálná megoldani az egyén). A kognitív viselkedésterápia ötvözi a kognitív és a viselkedésterápia technikáit. Segíti az embereket a hibás, torz gondolkodási folyamatok (kognitív torzítások, negatív automatikus gondolatok) felismerésében és megváltoztatásában, illetve maladaptív magatartásuk felismerésében, adaptívak kidolgozásában. ${ }^{13}$

A módszer strukturált, egyéni és csoportos formában is végezhető, gyakorisága heti 1-2 alkalom, az ülések között házi feladatként otthoni gyakorlatok végzése is a terápia szerves részét képezi. A módszer hatékony unipoláris depresszió, disztímia, szorongásos zavarok, pánikzavar, evészavar, poszttraumás stressz zavar, alkalmazkodási zavarok, bizonyos személyiségzavarok, pszichózisok pozitív tünetei, kapcsolati zavarok, obszesszív-kompulzív zavarok, krízisállapotok kezelésére. Nem alkalmazható akut pszichotikus állapotban, súlyos demencia esetén, tudatzavart állapotokban, mentális retar- dáció fennállásakor. A módszerrel megismerkedni a VIKOTE Kognitív és Sématerápiás Központban lehet, a képzési kínálatban jelenleg megtalálható a CBT konzultáns képzés is, ahol humán alapdiplomával rendelkezők is elsajátíthatják a módszert. Képeznek továbbá pszichoterapeutákat, és indítanak sématerapeuta képzést is. Pszichoterapeuta képzésre a jelen szabályozás szerint klinikai szakpszichológus, neuropszichológiai vagy alkal-mazott egészségpszichológiai szakvizsgával rendelkező pszichológusok, illetve szakorvosok jelentkezhetnek. ${ }^{13,14}$

\section{Célkitűzés}

A vizsgálat célja metaanalízisek és szisztematikus összefoglaló tanulmányok eredményeinek áttekintésével a Magyarországon is hozzáférhető stresszkezelő és kiégésmegelőző módszerek hatékonyságának összefoglalása a munkavállalók körében.

\section{MÓDSZERTAN}

A keresés adatbázisai: Ovid Medline, PsychInfo, Evidence Based Medicine Reviews, Cochrane Database of Systematic Reviews, ACP Journal Club, Database of Abstracts of Reviews of Effects, Cochrane Central Register of Controlled Trials, Cochrane Methodology Register, Health Technology Assessment, NHS Economic Evaluation Database. A címben, absztraktban, kulcsszavakban történő keresés keresőszavai a következők voltak: stress or burnout or burn-out; AND management or prevention or intervention or reduction or relief or cop* or decrease or training or program or workshop. További szúkitések: 18 év feletti korosztály; angol nyelvú; 2010 utáni cikkek; európai, amerikai és ausztrál populációra vonatkozó tanulmányok; metaanalízisek és szisztematikus review-k. A keresés szúkítése célcsoportok szerint: pedagógusok, egészségügyi dolgozók, munkavállalók. Továbbiakban beválogatásra kerültek azok a tanulmányok, amelyekben vizsgálták a következő módszereket: mindfulness alapú módszerek, relaxációs módszerek (autogén tréning, progresszív relaxáció), kognitív viselkedésterápiás módszerek.

A többszintű szűrést követően, a duplikációk áttekintése után 15 releváns tanulmány került be a vizsgálatba, amelyeket célcsoportok szerint mutatunk be. 


\section{EREDMÉNYEK}

\section{Munkavállalók és egészséges személyek körében hatékony beavatkozások}

Egészséges személyek körében hatékony stresszkezelő módszernek bizonyult az MBSR (Mindfulness based stress reduction) mind a stressz pszichológiai, mind a fiziológiai mutatói tekintetében. A stressz szintjének szignifikáns csökkentése mellett jótékony hatása igazolódott a szorongás csökkentésében is hozzájárulva a pszichológiai jólléthez. ${ }^{15,16,17}$ Továbbá a módszer csökkenti a ruminatív gondolkodást és növeli a spiritualitást, az empátiát és az önelfogadást. ${ }^{16} \mathrm{Az}$ MBSR magas erősségű evidenciát mutat a stressz csökkentésében nem klinikai populáció esetén. A pozitív hatás a beavatkozást követően 19 hét múlva is fennmarad. A stressz csökkentése mellett jótékony hatása közepes evidenciát mutat a szorongás, a depresszió és az életminőség területén. A módszer a kiégés csökkentésére is alkalmas, azonban az evidencia ebben az esetben alacsony szintû. ${ }^{17}$

Általában a munkahelyen a kognitív viselkedésterápia nagyobb hatékonyságot mutatott összehasonlítva más vizsgált intervenciókkal (pl. relaxáció, szervezeti vagy vegyes technikákkal) Richardson és Rothstein 2008 összefoglalója alapján. ${ }^{18} \mathrm{Az}$ összefoglalóban szereplő 36 tanulmány közül a legtöbb pszichológiai kimeneti változókat vizsgált (stressz, szorongás, általános mentális egészség, munkahelyi elégedettség), emellett szervezeti (hiányzás, termelékenység) és fiziológiai (pl. vérnyomás) változókat is mértek. A beavatkozások átlagosan 7,4 hétig tartottak.

A munkahelyeken alkalmazott mindfulness módszerek közepes, illetve erős hatásúnak bizonyultak a distressz csökkentésében Virgili 2015-ös összefoglalója alapján (19 tanulmányt vizsgált). Ezek a mindfulness beavatkozások átlagosan 5 hetes utánkövetéssel is megtartották jótékony hatásukat. A tanulmány további következtetése, hogy a munkahelyekre kifejlesztett rövidített változat ugyanolyan hatékonynak bizonyult, mint a klinikai felhasználásra kifejlesztett hosszabb változat (8 hetes). A beavatkozások időtartama 4 és 8 hét között volt. Arra azonban kevés bizonyítékot találtak, hogy a mindfulness módszerek sokkal hatékonyabbak lennének, mint más relaxációs módszerek. ${ }^{19}$

A rugalmas munkaidő-beosztás, a távmunka és a stresszkezelő tréningek (kognitív viselkedésterápia, relaxáció) alkalmazása javítja a munkavállalók mentális egészségét, munkateljesítményét, és csökkenti a hiányzást Kröll és munkatársai (2017) összefoglaló tanulmánya alapján. ${ }^{20} \mathrm{~A}$ vizsgált változókkal összefüggésben a legnagyobb hatásméretet a relaxációs módszereknél mutatták ki (mentális egészség, munkateljesítmény).

Munkavállalók körében a kiégés csökkentésében a leggyakrabban használt módszerek a mindfulness és a kognitív viselkedésterápia alapú beavatkozások Jaworska-Burzynska és munkatársai (2016) összefoglalója alapján. A legtöbb intervenció 8 hétig tartott és a hatás egy évig is fennmaradt. ${ }^{21}$

\section{Hatékony beavatkozások egészségügyi dolgozók körében}

Az egészségügyi dolgozók vizsgálata során a munkahelyi stressz csökkentésének két lehetséges beavatkozási irányát különbözteti meg a szakirodalom: egyénközpontú intervenciók (kognitív viselkedésterápia-alapú (CBT) programok, relaxáció, zene, fizikai relaxáció (pl. masszázs) és multikomponensű beavatkozások), illetve a munkára és/vagy munkakörülményekre irányuló intervenciók (attitűdváltozás és kommunikáció, társas támogatás, problémamegoldás és döntéshozás, munkaszervezetet érintő változások). ${ }^{22}$

A stressz csökkentésében az intervenció nélküli helyzettel szemben az egyénközpontú intervenciókat és szervezeti beavatkozásokat vizsgálva a következő eredmények adódtak: a CBT alapú programok akár relaxációs technikákkal kiegészítve, akár azok nélkül, hatékonyabbak az intervenció nélküli, kontrollhelyzethez képest, de a többi intervencióval összehasonlítva nem mutatnak jelentős különbséget; a fizikai lazítás (pl. masszázs), relaxáció vagy meditáció szintén jótékony hatással bír a stressz csökkentésében. ${ }^{22}$

Konklúzióként megfogalmazható, hogy az egyénre irányuló, egyén-munka összeillésre vonatkozó és szervezeti intervenciók, összevetve az intervenció nélküli helyzettel, szignifikánsan pozitív változást képesek előidézni a stressz és a kiégés csökkentésében és megelőzésében. Az egyénre vonatkozó beavatkozások az érzelmi kimerülésen és a személyes teljesítményen keresztül hatnak, így csökkentve a stressz és kiégés szintjét. ${ }^{22}$

Egészségügyi dolgozók körében, akik magas érzelmi megterhelés mellett dolgoznak, a kiégés kiemelt probléma a munkaerőpiacon. Esetükben a 
mindfulness programok munkahelyi kiégést csökkentő és kiégéssel szembeni rezilienciát növelő hatását magas evidenciaszintű tanulmányok igazolják. Egészségügyi dolgozók, úgymint orvosok, nővérek, pszichológusok és szociális munkások részvételével zajló nyolchetes MBSR tréning vizsgálata során a kiégés mértékének csökkenését rögzítették. ${ }^{23}$

A mindfulness tréningek többféle változat szerinti alkalmazása is kimutatható csökkenést jelzett a kiégést illetően, ilyenek voltak a módosított és a hagyományos MBSR tréningek (8 hetes, 3 hónapos utánkövetéssel), illetve a rövidített mindfulness tréningek (4 hetes, 30 perces alkalmakkal, heti 5 napon keresztüli 10 perces gyakorlással). Előbbi csökkentette a kiégést, azon belül is kiemelten az emocionális kimerülést mind egészségügyi dolgozók, nővérek, szociális munkások, lelkipásztorok, mind tanárok esetében. A kontrollcsoportnál azonban ez az érték (érzelmi kimerültség) és a deperszonalizáció is emelkedést mutattak. ${ }^{23}$

Egy európai tanulmány szerint, amely dolgozók széles körét vizsgálta (hivatalnokok, bankárok, kereskedők, nővérek, tanárok, szociális munkások, pszichológusok stb.) a mindfulness programok abban az esetben is az érzelmi kimerültség csökkent szintjével jártak együtt, ha a mindfulness-gyakorlatokat egyénileg, önirányítottan 10 napon keresztül végezték. ${ }^{23}$

Azok az egészségügyi dolgozók, akik mentális betegségekkel érintett páciensekkel dolgoznak pszichológusok, pszichiáterek, szociális munkások a kiemelten magas stressznek kitett célcsoporthoz tartoznak, összehasonlítva más foglalkozásokkal, hiszen fokozott érzelmi megterhelésnek vannak kitéve hosszú időn keresztül, ami a kiégés kockázatát jelentősen megemeli, az MBSR, valamint az Elfogadás és Elköteleződés Terápia (ACT) hatásaként csökkent körükben a stressz. Rudaz és mtsai (2017) tanulmányai szerint a mindfulness fontos szerepet játszik a mentális egészségben az öngondoskodást illetően, de egyelőre tisztázatlan maradt, hogy a mindfulness mely komponensei a döntőek a stressz csökkentésében. ${ }^{24}$

Az egészségügyi dolgozók, illetve kifejezetten az ápolók stresszel és stresszkezeléssel kapcsolatos vizsgálata széles körü, a tanulmányok fókuszát az egyéni, személyre irányuló faktorokat, a munkakörnyezetet/szervezetet, illetve a kettő kombinációját magába foglaló beavatkozások adják. ${ }^{25}$ Ennek alapján alacsony evidencia mellett az egyéni támogatást célzó intervenciókat találták hatásosnak, különös tekintettel a kognitív technikákon alapuló intervenciókra, a zene- és relaxációs tréningekre, társas támogatást célzó képzésekre. Későbbi vizsgálatokban nővérképzésben részt vevő hallgatók stressz szintjének csökkentését célzó intervenciók közül, szintén az egyéni intervenciók bizonyultak hatékonynak. Ezek közül is azok, amelyek a stresszhelyzetekkel való megküzdést segítették - jellemzően relaxációval -, illetve a maladaptív kogníciók megváltoztatásával. ${ }^{26}$

Spirituális beavatkozásokat vizsgálva Koren és Purohit (2014) az áttekintésük során azt találták, hogy a mindfulness-intervenció a leggyakrabban és talán a leghatékonyabban használt módszer, de az egyéb módszerek, mint a reiki, a meditáció, a jóga különféle formái, a mantra és a szív érintése is emelték a résztvevőkben a tudatosság és a figyelem mértékét. $^{27}$

\section{Hatékony beavatkozások pedagógusok körében}

A pedagógusok körében szintén kiemelt probléma a kiégés, mivel magas érzelmi megterhelés mellett dolgoznak. A tanárok magas stressz melletti munkavégzésének jelentős negatív hatása van a diákokkal végzett munkájuk iránti elköteleződésükre és hatékonyságukra. ${ }^{28} \mathrm{~A}$ munkavégzés során átélt stressz fizikai és mentális egészséggel kapcsolatos problémákhoz vezet, negatív hatással van a jóllét érzésére. ${ }^{29}$ Azonban a korai intervenció és a megelőzés hozzájárulhat pozitív megküzdési stratégiák kiépítéséhez és a stressz hatásainak csökkentéséhez, melynek egyik hatékony módja lehet a mindfulness alapú intervenció (MBI). A tanárok szociális és érzelmi kompetenciáinak támogatása ezen programokon keresztül javítja a tanár-diák kapcsolatokat és az osztályok hatékony vezetésének képességét, melyek hozzájárulnak a tanulók jóllétéhez is. ${ }^{30}$

A mindfulness alapú intervenciók (MBI) hatásosnak bizonyultak a stressz szintjének csökkentésében, hatékonyak az érzelemszabályozási stratégiák kialakításában és a szakmai énhatékonyság növelésében. Az MBI hatása a stressz (beleértve a kiégést is) által kialakuló fizikai és pszichológiai tünetek csökkentésében is megmutatkozik, de legfontosabb eredménye az észlelt stressz csökkentésében jelenik meg. ${ }^{28}$

A tanárok között vizsgálták a mindfulness alapú stresszcsökkentő program (MBSR) hatékonyságát is. Általános iskolai tanárok számára megtartott 
MBSR tréning hatásaként javulás mutatkozott stressz, szorongás és depresszió területén, mint ahogyan a stressz csökkentésében hatásosnak bizonyult a tanárok számára szervezett öt hetes meditációs csoport is. ${ }^{31}$ A mindfulness programok munkahelyi kiégést csökkentő hatásait, a kiégéssel szembeni hatásos megelőzési módjait körükben is magas evidenciaszintű tanulmányok igazolják. ${ }^{31}$ A mindfulness tréningek többféle változata csökkenést eredményezett a kiégést illetően, ezek voltak a módosított és a hagyományos MBSR tréningek, rövidített mindfulness tréningek. Egy európai tanulmány szerint a mindfulness programok abban az esetben is az érzelmi kimerültség csökkent szintjével jártak együtt, ha a mindfulness gyakorlatokat egyénileg, önirányítottan tíz napon keresztül végezték el. Kifejezetten tanároknak kidolgozott 30 órás, 5 üléses program - melyet telefonhívásokkal és egy hónappal későbbi, kontrollüléssel támogattak meg - a személyes énhatékonyság érzésének növekedését hozta, szemben a kontrollcsoporttal.

\section{ÖSSZEGZÉS}

Metaanalízisek és szisztematikus tanulmányok áttekintése alapján a mindfulness alapú programok magas evidenciaszint mellett csökkentették a stressz és kiégés mértékét. A kognitív viselkedésterápiás technikák ugyan alacsony evidencia mellett, de a mindfulness alapú programok után a legerősebb bizonyítékkal rendelkező módszerek a vizsgált célcsoportokban. A relaxációs módszerek a stresszkezelésben szintén alacsony evidenciával rendelkeznek, azonban pozitív hatásuk szúkebb körü kutatási eredményekkel alátámasztott és kifejezett előnyük, hogy Magyarországon széles körben hozzáférhetők.

Az összefoglaló tanulmányok összegzésének előnye, hogy a stresszkezelést és kiégésmegelőzést célzó módszerek hatékonyságáról szóló bizonyítékok széleskörű áttekintésére adott lehetőséget. A választott módszer hátrányai között kell említeni, hogy a szisztematikus áttekintő tanulmányok és metaanalízisek összefoglalóiban elemzett tanulmányok minősége heterogén, amelyet az eredmények értelmezésénél is figyelembe kell venni, mint korlát. Az ismertetett kutatások eredményei alapján mindhárom módszer akár egy adott szakmacsoporton belül vagy szélesebb célcsoportot is tekintve hatékony stresszcsökkentő és kiégésmegelőző eszköz lehet.

\section{HIVATKOZÁSOK}

\footnotetext{
${ }^{1}$ Ursin H, Eriksen HR. The cognitive activation theory of stress. Psychoneuroendocrinology. 2004;29(5):567-592. DOI: 10.1016/S0306-4530(03)00091-X

2 Salavecz Gy. Munkahelyi stressz és egészségi állapot összefüggése a Hungarostudy 2013-as felmérés alapján. In Susánszky Éva (szerk.), Szántó Zsuzsa (szerk.): Magyar lelkiállapot, 2013.

${ }^{3}$ Dhabhar FS. Stress-induced augmentation of immune function - The role of stress hormones, leukocyte trafficking, and cytokines. Brain, Behavior, and Immunity. 2002;16:785-798. DOI: 10.1016/s0889-1591(02)00036-3

${ }^{4}$ Stauder A, Nistor K, Susánszky É, et al. Egyes személyiségjellemzők szerepe a stressz észlelésében és a megküzdésben. In.: Susánszky, É. és Szántó Zs. szerk., Magyar Lelkiállapot, Semmelweis Kiadó, Budapest, 2013. pp123-136.

${ }^{5}$ Rosengren A, Hawken S, Ôunpuu S, et al. Association of psychosocial risk factors with risk of acute myocardial infarction in 11119 cases and 13648 controls from 52 countries (the INTERHEART study): case-control study. The Lancet. 2004;364(9438):953-962. DOI: 10.1016/S0140-6736(04)17019-0

${ }^{6}$ Freudenberger HJ, Richelson G. Burnout: The High Cost of Achievement. Doubleady and Company, 1980.

${ }^{7}$ Kristensen T. S, Borritz M, Villadsen, E.\& Christensen K. B,: The Copenhagen Burnout Inventory: A new tool for the assessment of burnout. Work and Stress, 19(3), 2005. 192-207.

${ }^{8}$ Ádám Sz., Nistor A., Nistor K., Cserháti Z. és Mészáros V. A kiégés és a depresszió diagnosztizálásának elősegítése demográfiai és munkahelyi védő-és kockázati tényezőik feltárásával egészségügyi szakdolgozók körében. Orvosi Hetilap. 2015;156:32:1288-1297.

${ }^{9}$ Davis M, Eshelman ER, McKay M. Stresszoldó és relaxációs módszerek. Budapest: Park Könyvkiadó, 2013.

${ }^{10}$ Bagdy E, Koronkai B. Relaxációs módszerek. Medicina kiadó, Budapest, 1992.
} 
${ }^{11}$ Eberth J, Sedlmeyer P. The effects of mindfulness meditation: A meta-analysis. Mindfulness. 2012; (3):174-189. doi.org/10.1007/s12671-012-0101-x

${ }^{12}$ Chiesa A, Serretti A. A systematic review of neurobiological and clinical features of mindfulness meditations.

Psychological medicine. 2010;40(8):1239-1252. DOI: 10.1017/S0033291709991747

${ }^{13}$ http://oxfordmindfulness.org/ Elérve: 2020.03.25.

${ }^{14} \mathrm{http}: / /$ mindfulnessegyesulet.hu/oxford-mbct-tanar-kepzes/ Elérve: 2020.03.05.

${ }^{15}$ http://vikote.hu Elérve: 2020.03.25.

${ }^{16}$ NICE Guideline Depression in adults with a chronic physical health problem: recognition and management (2009). https://www.nice.org.uk/guidance/CG91 Elérve: 2020.03.25.

17 Sharma M, Rush SE. Mindfulness-based stress reduction as a stress management intervention for healthy individuals: a systematic review. J Evid Based Complementary Altern Med. 2014;19(4):271-286. DOI:10.1177/2156587214543143.

${ }^{18}$ Chiesa A, Serretti A. Mindfulness-based stress reduction for stress management in healthy people: a review and meta-analysis. J Altern Complement Med. 2009;15(5):593-600. DOI:10.1089/acm.2008.0495.

${ }^{19}$ Khoury B, Sharma M, Rush SE, et al. Mindfulness-based stress reduction for healthy individuals: A meta-analysis. J Psychosom Re. 2015;78(6):519-528. DOI:10.1016/j.jpsychores.2015.03.009.

${ }^{20}$ Richardson KM, Rothstein HR. Effects of occupational stress management intervention programs: a meta-analysis. J Occup Health Psychol. 2008;13(1):69-93. DOI:10.1037/1076-8998.13.1.69.

${ }^{21}$ Virgili M. Mindfulness-Based Interventions Reduce Psychological Distress in Working Adults: a Meta-Analysis of Intervention Studies. Mindfulness. 2015;6(2):326-337. doi.org/10.1007/s12671-013-0264-0

${ }^{22}$ Kroll C, Doebler P, Nuesch S. Meta-analytic evidence of the effectiveness of stress management at work. European Journal of Work and Organizational Psychology. 2017;26(5). DOI: 10.1080/1359432X.2017.1347157

${ }^{23}$ Jaworska-Burzynska L, Kanaffa-Kilijanska U, Przysiezna E, et al. The role of therapy in reducing the risk of job burnout - A systematic review of literature. Archives of Psychiatry and Psychotherapy. 2016;4:43-52 DOI:10.12740/APP/65815.

${ }^{24}$ Ruotsalainen JH, Verbeek JH, Mariné A, et al. Preventing occupational stress in healthcare workers. Cochrane Database Syst Rev. 2014;(12):CD002892 doi: 10.1002/14651858.CD002892.pub4.

${ }^{25}$ Luken M, Sammons A. Systematic Review of Mindfulness Practice for Reducing Job Burnout. Am J Occup Ther. 2016;70(2):7002250020p1-7002250020p10. doi: 10.5014/ajot.2016.016956

${ }^{26}$ Rudaz M, Twohig MP, Ong CW. et al. Mindfulness and acceptance-based trainings for fostering self-care and reducing stress in mental health professionals: A systematic review. J Contextual Behav Sci. 2017;6:380-390.

doi:10.1016/j.jcbs.2017.10.001

${ }^{27}$ Mimura C, Griffiths P. The effectiveness of current approaches to workplace stress management in the nursing profession: an evidence based literature review. Occup Environ Med. 2003;60(1):10-15. doi: 10.1136/oem.60.1.10

${ }^{28}$ Galbraith ND, Brown KE. Assessing intervention effectiveness for reducing stress in student nurses: quantitative systematic review. J Adv Nurs. 2011;67(4):709-721. DOI: 10.1111/j.1365-2648.2010.05549.x

${ }^{29}$ Koren ME, Purohit S. Interventional studies to support the spiritual self-care of healthcare practitioners: an integrative review of the literature. Holist Nurs Pract. 2014;28(5):291-300. DOI: 10.1097/HNP.0000000000000044

30 Emerson LM, Leyland A, Hudson K, et al. Teaching Mindfulness to Teachers: a Systematic Review and Narrative Synthesis. Mindfulness. 2017;8(5)1136-1149. DOI: 10.1007/s12671-017-0691-4

${ }^{31}$ Naghieh A, Montgomery P, Bonell CP, et al. Organisational interventions for improving wellbeing and reducing work-related stress in teachers. Cochrane Database Syst Rev. 2015;4(4)CD010306. doi: 10.1002/14651858.CD010306.pub2 